\title{
Assessment of Bending Properties of Sawn and Glulam Blackwood in Portugal
}

\author{
Carlos Martins ${ }^{1}\left(\mathbb{D}\right.$, Sandra Monteiro ${ }^{1, *} \mathbb{*}$, Sofia Knapic ${ }^{1,2}$ and Alfredo Dias ${ }^{1}$ \\ 1 Civil Engineering Department, Institute for Sustainability and Innovation in Structural Engineering, \\ University of Coimbra, Rua Luís Reis Santos-Pólo II, 3030-788 Coimbra, Portugal; cmartins@serq.pt (C.M.); \\ sknapic@serq.pt (S.K.); alfgdias@dec.uc.pt (A.D.) \\ 2 SerQ-Forest Innovation and Competences Center, Rua J, Nº 9, Zona Industrial da Sertã, \\ 6100-711 Sertã, Portugal \\ * Correspondence: sandra@dec.uc.pt
}

Received: 14 March 2020; Accepted: 7 April 2020; Published: 9 April 2020

\begin{abstract}
Portuguese forests have changed in recent years. These changes were mainly boosted by the wildfires that affected a significant percentage of the softwood area. Data from 2015, conveyed by the Portuguese Institute for Nature Conservation and Forests, indicates that hardwoods occupy 70\% of the Portuguese forest area. This paper presents the Blackwood (Acacia melanoxylon R. Br.) species potential, focusing on construction applications, based on recent studies performed at the University of Coimbra and SerQ-Forest Innovation and Competences Center. The valuation of Blackwood for structural applications has been considered through the non-destructive and destructive assessment of their mechanical properties as sawn wood. Their potential was also assessed for a more technologically engineered wood product, the glulam. The dynamic modulus of elasticity (MOE) was estimated through the Longitudinal Vibration Method (LVM) and the Transformed Section Method (TSM); the static MOE and bending strength were assessed through a four-point bending test. Agreement was obtained between both approaches. Sawn Portuguese Blackwood showed a density of $647 \mathrm{~kg} / \mathrm{m}^{3}$, $13,900 \mathrm{MPa}$ of MOE and a bending strength of $65 \mathrm{MPa}$ (mean values). The glulam beams fabricated with this raw material had improved properties relative to sawn wood, most obviously concerning the bending strength, with an improvement of $29 \%$. This proves the significant ability and potential of these species to be used in construction products with structural purposes like sawn wood and glulam.
\end{abstract}

Keywords: Portuguese hardwoods; blackwood; mechanical characterization; construction applications

\section{Introduction}

Portuguese forests and the wood products obtained from them represent a significant contribution to the Portuguese economy, being responsible for 3\% of Gross Domestic Product in 2015 [1]. Data from the Sixth National Forestry Census [2] indicated that $36.2 \%$ of the Portuguese land area is occupied by forest, totaling 3,224,200 ha, which is close to the mean of all European Union countries (37.6\%). The same report lists the 22 most common species grouped in softwoods (7) and hardwoods (15). The higher number of hardwood species is in line with the occupied area, 2,259,300 ha, representing 70\%, with Blue gum being the dominant species (26\%), followed by Cork Oak (22\%), Holm Oak (11\%), Oak $(3 \%)$, Chestnut (1\%), Acacia (0.3\%) and a group of other hardwoods (Poplar, Beech, Ash, and others, $6 \%$ ). Portuguese law prohibits the felling of species like Cork Oak and Holm Oak, unless duly and previously authorized, which means that, in most the cases, only branches from thinning are available, resulting in a material with dimensions unsuitable for construction applications. This implies a decrease in the available area of hardwood forests for these applications by approximately $37 \%$. 
In past decades, European hardwoods have been the focus of research due to their potential in terms of mechanical properties, as well as their potential for use in foreseeing the threats of climatic changes like Ash and Maple [3,4], Beech [5,6], and Birch [7]. In recent years, some studies have been developed considering the assessment of the potential of some hardwoods available in the Portuguese forest for glulam production, such as Poplar [8-11] and Blue gum [12].

According to Knapic et al. [13], Blackwood (Acacia melanoxylon R. Br.) has its origin in the temperate forests of south-east Australia and Tasmania and is considered a versatile and highly adaptive tree species being spread all over the world due to its ornamental value and the dark color of the wood, which makes it aesthetically appealing (Figure 1). Despite the quality of wood, in Europe, these species are considered invasive, since being a non-indigenous species they unbalance the structure or functioning of an ecological system, with the particularity that the seeds are stimulated by fire [13]. Knapic et al. [13] also state that, in Portugal, Blackwood occurs mainly in mixed stands with Maritime pine (Pinus pinaster Ait.) or Stone pine (Pinus pinea L.) in the West Coast or in pure stands or mixed with pines and other hardwoods in the inner part of Portugal.

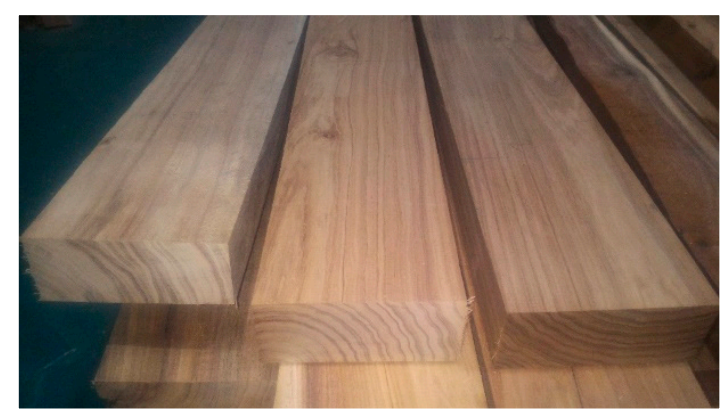

Figure 1. Blackwood visual aspect.

Blackwood species was introduced in Portugal as an ornamental in the mid-19th century and its expansion occurred in the first half of the 20th century through national forestation programs, in which the afforestation projects of coastal dunes included exotics such as Acacia, Casuarina and Eucalyptus $[14,15]$. Blackwood is considered mainly for carpentry and cabinet applications, being typically highly valued. Several scientific studies have been developed on Blackwood, mainly focused on the silviculture of the species [16-18], anatomic properties [13,19] and physical properties [20]. Moreover, the potential for pulp and paper production was evaluated, showing great potential [21,22], especially for writing and printing paper production [23]. Machado et al. [20] evaluated the variation between trees (longitudinal and radial direction) in the physical properties (density) and mechanical properties of Blackwood in clear wood specimens collected from four different stands. The authors evidenced the potential of Blackwood as an alternative species to supply the industry with valuable hardwood timber. Mean values of density, modulus of elasticity (MOE) and bending strengths of $654 \mathrm{~kg} / \mathrm{m}^{3}, 14,100 \mathrm{MPa}$ and 139.0 MPa were obtained, respectively. The significant differences found between trees are pointed out as the knowledge needed for an accurate selection of the raw material to increase the wood quality. A study focusing on the density and growth of Blackwood in different sites in Portugal showed a mean ring width of $6 \mathrm{~mm}$ in 27-56-year-old trees [24]. These values are lower than other results found in other studies: $14 \mathrm{~mm}$ in 7-year-old [25], 6-7 $\mathrm{mm}$ in 7-21-year-old natural trees [26].

The knowledge of the mechanical properties of several hardwoods available in the Portuguese forest is becoming well defined. However, the characterization of Blackwood's potential is scarce and is focused on clear wood. Research was carried out at SerQ-Forest Innovation and Competences Center, aiming to assess the key bending properties (modulus of elasticity and bending strength) and evaluate the mechanical performance of a large sample of sawn wood with cross-sectional dimensions of $50 \times 120 \mathrm{~mm}^{2}$ (thickness $\times$ width). Non-destructive tools were used to predict those properties through simple linear correlation analyses. The Longitudinal Vibration Method (LVM), which consists 
of the measurement of the material's natural frequency, was used, since it was previously validated for other species, like Maritime pine [27], Poplar [28] and Blue gum [29]. The present paper intends to improve the knowledge of the Portuguese Blackwood for structural applications, highlighting the species' potential to produce glulam as a way to add value to the raw material obtained from the proliferation of the species. It aims also to confirm the reliability of using non-destructive techniques, such as the LVM, as a predictor of the MOE, allowing resource optimization. Therefore, sawn wood from two different provenances was collected to access their mechanical properties and the LVM. Then, the glulam beams were fabricated to evaluate their potential by assessing their bending MOE and bending strength.

\section{Materials and Methods}

\subsection{Portuguese Blackwood as Sawn wood: Raw-Material Characterization}

Two samples of 40 boards each, from two different provenances, the Azores Islands (AI) and the North of Portugal (NP), were assessed in their dimensions (thickness, width, and length), moisture content and weight. The cross-section dimensions were measured in three different locations (both ends and mid-length). The moisture content was recorded by an electrical moisture meter at mid-length and $600 \mathrm{~mm}$ from each end, as required by EN 13183-2 [30] (Figure 2a). The referred data was considered as the input for the software of the device used (Timber Grader MTG) to assess the dynamic MOE through the LVM (Figure 2b). This device only requires access to one end of the element to be tested (the stress wave activator and the stress wave detector are located at the same device). The wave travels through the element and returns to the device. The wave frequency is sent to a computer, via a Bluetooth interface, which combines the input data and provides the dynamic MOE. Martins et al. [31] carried out a study on 18 glulam beams made of Poplar to assess the efficiency of this non-destructive method to predict both MOE and bending strength.

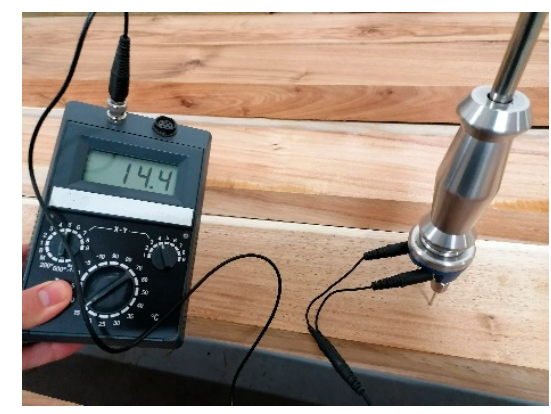

(a)

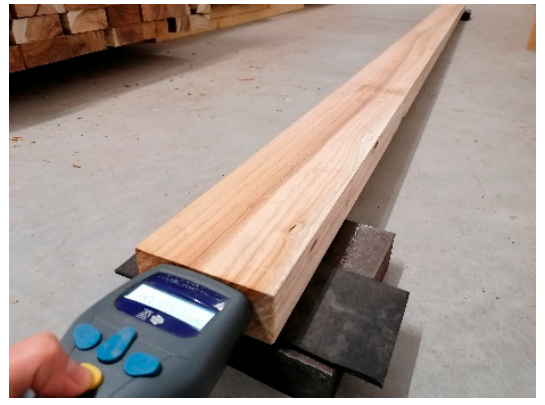

(b)

Figure 2. Measurement of: (a) the moisture content; and (b) of the dynamic modulus of elasticity (MOE) test.

After the non-destructive test, the dynamic MOE of each board $\left(E_{d y n-b}\right)$ was recorded and static tests were performed as a four-point bending test, according to EN 408 [32]. The static MOE test was performed with a displacement constant rate $(0.36 \mathrm{~mm} / \mathrm{s})$ up to $40 \%$ of the estimated failure load, to obtain the static MOE of each board $\left(E_{\text {global-b}}\right)$. The applied load was measured by a load cell (with $200 \mathrm{kN}$ of maximum capacity) and deflections were measured by displacement transducers with 20 and $50 \mathrm{~mm}$ maximum capacities. The bending strength parallel to the grain $\left(f_{m}\right)$ was determined by a destructive test, applying the load with a displacement constant rate of $(0.17 \mathrm{~mm} / \mathrm{s})$ up to failure. Section 3.1 summarizes the boards' results. 


\subsection{Portuguese Blackwood Glulam Beams: Assembly and Mechanical Characterization}

For the mechanical characterization of glulam beams made with Blackwood, eight glulam beams (BWi, with $\mathrm{i}=1-8$ ) were produced at the SerQ laboratory. A set of 40 boards with mean nominal dimensions of $50 \times 121 \times 2901 \mathrm{~mm}^{3}$ (thickness $\times$ width $\times$ length) was selected. All boards were weighted and non-destructively characterized. Their mean density and dynamic MOE ( \pm standard deviation) were $665 \pm 82 \mathrm{~kg} / \mathrm{m}^{3}$ and 13,864 $\pm 2,177 \mathrm{MPa}$, respectively.

Each board was planed to a final thickness of $24 \mathrm{~mm}$, cut to a final width of approximately $100 \mathrm{~mm}$, and $2400 \mathrm{~mm}$ nominal length. The lamellae were, again, non-destructively assessed and each group was then arranged into the final glulam beam configuration, based on the dynamic MOE of each lamella $\left(E_{d y n_{-} l}\right)$ (Figure 3, where $E_{d y n-l-a v}$ is the mean $E_{d y n_{-} l}$ of each beam). The boards were sorted into groups of five for the production of three homogeneous (BW5, BW7, and BW8) and five combined glulam beams (BW1 to BW4, and BW6). The lamellae with lower values of $E_{d y n \_} l$ were adopted as the central layer and the higher values were arranged at the outer layers, ascending from the inner to the outer layers, resulting in a symmetrical display. The authors categorized as homogenous the beams whose lamellae had a range of variation of dynamic MOE lower than those considered as combined (Figure 3). The gluing process was performed in controlled conditions of temperature $\left(20 \pm 2{ }^{\circ} \mathrm{C}\right)$ and relative humidity $(65 \pm 5 \%)$. Two different adhesives, one-component polyurethane (1C-PUR-1 and 1C-PUR-2), were used. The technical data sheets regarding the amount of adhesive, clamping pressure and assembly time were followed. The adhesive was spread manually, with the amount applied controlled by weighing. The 1C-PUR-1 $\left(180 \mathrm{~g} / \mathrm{m}^{2}\right)$ was used for BW1 and BW2 glulam beams. It was applied after the primer application (PR $3105-20 \mathrm{~g} / \mathrm{m}^{2}$ ) and a minimum activation period of $10 \mathrm{~min}$. The adhesive 1C-PUR-2 $\left(200 \mathrm{~g} / \mathrm{m}^{2}\right)$ was used for the remaining beams. For both adhesives, 1.0 MPa was considered as the pressure level, applied by a series of hydraulic jacks spaced by $500 \mathrm{~mm}$ and with a maximum load capacity of 5 tons each (Figure $4 \mathrm{a}$ ).

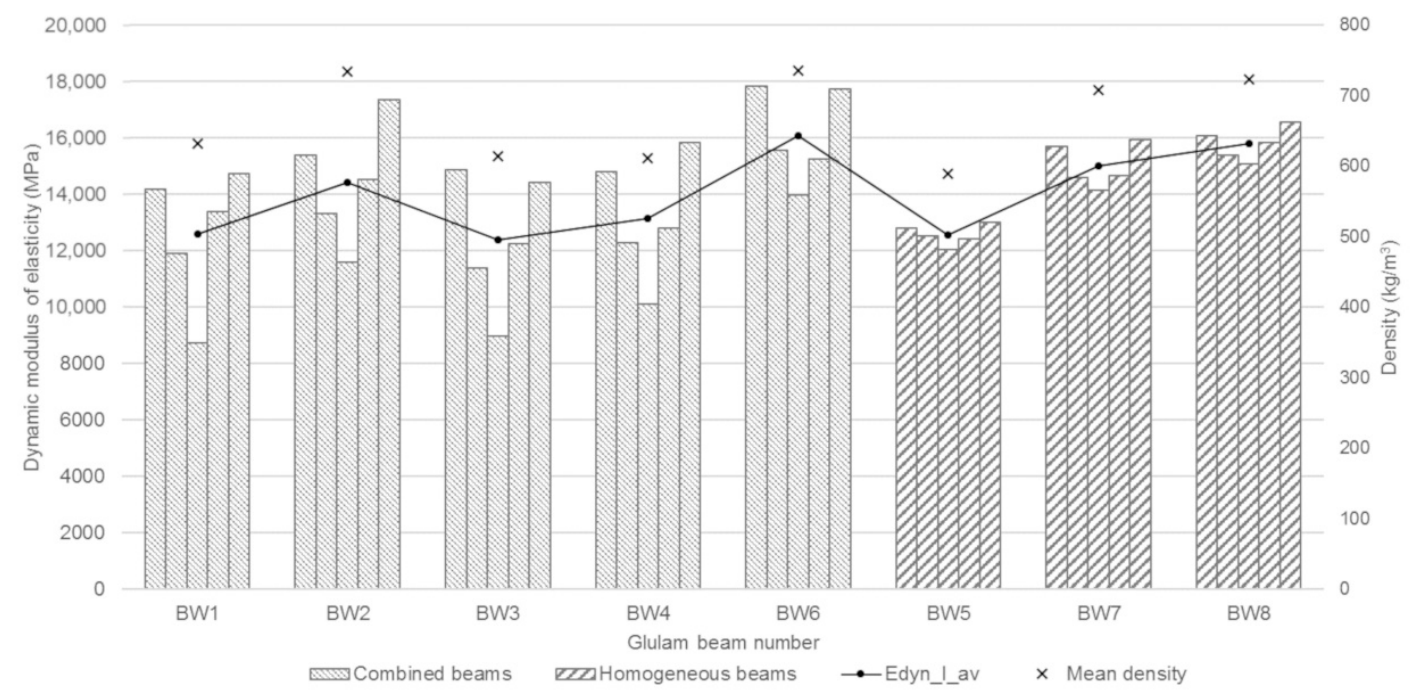

Figure 3. Summary of $E_{d y n-l}$ of individual lamellae and $E_{d y n-l-a v}$ for the Blackwood glulam beams. 


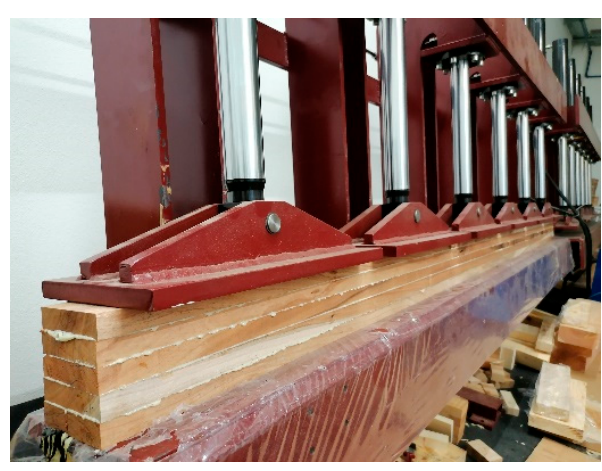

(a)

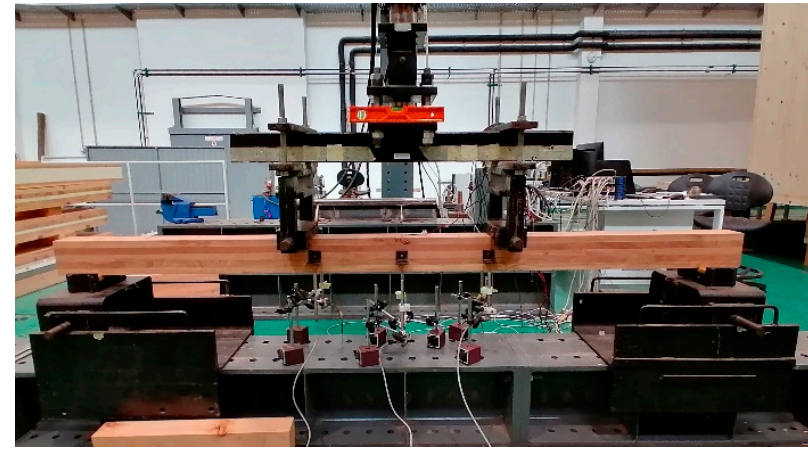

(b)

Figure 4. Blackwood glulam beam: (a) at a production stage under pressure; (b) subjected to a static MOE test.

A curing period of 7 days at the referred controlled conditions was considered. The glulam beams were planed laterally to a final width of $92 \mathrm{~mm}$ and cut to $2350 \mathrm{~mm}$ length. The beams were weighed and measured before non-destructive tests with the LVM to obtain the dynamic MOE $\left(E_{d y n}\right)$. The prediction of static MOE was also considered by the use of the Transformed Section Method (TSM) $\left(E_{T S M}\right)$. The TSM considers a cross-section with homogeneous properties, instead of the actual heterogeneous one, which allows for the application of conventional beam theory elastic formulas. Martins et al. [31] adopted both methods for glulam beams made by Portuguese Poplar, with both showing great potential as predictors of static MOE.

Finally, static MOE and bending strength tests were performed. The test layout, loading procedures applied and measuring devices considered were the same as those applied for the sawn wood tests (Figure $4 \mathrm{~b}$ ). After failure tests, the density and moisture content of each glulam beam was determined by one specimen with approximately $50 \mathrm{~mm}$ length and full cross-section. Section 3.2 summarizes the glulam beams' results.

\section{Results and Discussion}

\subsection{Portuguese Blackwood Sawn Wood}

The boards of the AI sample had a mean moisture content of $11 \%$ and mean dimensions of $49 \times$ $118 \times 2201 \mathrm{~mm}^{3}$ (thickness $\times$ width $\times$ length). As for the NP sample, the boards had a mean moisture content of $12 \%$ and mean dimensions of $50 \times 121 \times 2898 \mathrm{~mm}^{3}$ (thickness $\times$ width $\times$ length).

Tables 1-3 gather the values obtained for the entire set of sawn wood, the AI sample and the NP sample, respectively, namely: dynamic and static MOE, bending strength, moisture content $(w)$ and density of a piece with no defects $(\rho)$, the values of density and static MOE adjusted for a $w=12 \%$ ( $\rho_{12 \%}$ and $E_{\text {global-b-12\%, }}$, respectively) computed based on the EN 384 [33] and the values of the bending strength adjusted $\left(f_{m-a d j}\right)$ based on the recommendations of EN 14,080 [34]. The characteristic values (Char.val.) were computed considering the $5 \%$ percentile.

Table 1. Physical and mechanical properties for the entire sawn wood sample.

\begin{tabular}{ccclccccc}
\hline & $\begin{array}{c}\boldsymbol{E}_{\text {dyn-b }} \\
\mathbf{M P a}\end{array}$ & $\begin{array}{c}\boldsymbol{E}_{\text {global-b }} \\
\mathbf{M P a}\end{array}$ & $\begin{array}{l}f_{m} \\
\mathbf{M P a}\end{array}$ & $\begin{array}{c}w \\
\mathbf{\%}\end{array}$ & $\begin{array}{c}\rho \\
\mathbf{k g} / \mathbf{m}^{\mathbf{3}}\end{array}$ & $\begin{array}{c}\boldsymbol{\rho}_{\mathbf{1 2} \%} \mathbf{1} \\
\mathbf{k g} / \mathbf{m}^{\mathbf{3}}\end{array}$ & $\begin{array}{c}E_{\text {global-b-12\%}} \mathbf{1} \\
\mathbf{M P a}\end{array}$ & $\begin{array}{c}f_{\text {m-adj }}{ }^{\mathbf{2}} \\
\mathbf{M P a}\end{array}$ \\
\hline Mean & 14,104 & 14,038 & 68.6 & 11.5 & 646 & 647 & 13,908 & 65.2 \\
Minimum & 9420 & 8399 & 26.8 & 9.1 & 492 & 493 & 8618 & 25.7 \\
Maximum & 20,054 & 20,520 & 130.1 & 16.8 & 803 & 808 & 19,552 & 123.8 \\
COV: $\%$ & 15.5 & 16.1 & 30.2 & 14.4 & 14 & 14 & 16.3 & 30.4 \\
Char.val. & - & - & - & - & - & 518 & 10,402 & 36.9 \\
\hline
\end{tabular}

${ }^{1}$ Computed according to EN 384 [33]. ${ }^{2}$ Computed according to EN 14,080 [34]. 
Table 2. Physical and mechanical properties for the AI sawn wood sample.

\begin{tabular}{ccclccccc}
\hline & $\begin{array}{c}\boldsymbol{E}_{\text {dyn-b }} \\
\mathbf{M P a}\end{array}$ & $\begin{array}{c}\boldsymbol{E}_{\text {global-b }} \\
\mathbf{M P a}\end{array}$ & $\begin{array}{l}f_{m} \\
\mathbf{M P a}\end{array}$ & $\begin{array}{c}w \\
\mathbf{\%}\end{array}$ & $\begin{array}{c}\rho \\
\mathbf{k g} / \mathbf{m}^{\mathbf{3}}\end{array}$ & $\begin{array}{c}\rho_{\mathbf{1 2} \%} \mathbf{1} \\
\mathbf{k g} / \mathbf{m}^{\mathbf{3}}\end{array}$ & $\begin{array}{c}E_{\text {global-b-12\%}} \mathbf{1} \\
\mathbf{M P a}\end{array}$ & $\begin{array}{c}f_{\text {m-adj }}{ }^{\mathbf{2}} \\
\mathbf{M P a}\end{array}$ \\
\hline Mean & $13,452^{\mathrm{b}}$ & 13,648 & 65.0 & 11.0 & 590 & $593^{\mathrm{b}}$ & $13,351^{\mathrm{b}}$ & $61.0^{\mathrm{a}}$ \\
Minimum & 10,726 & 9954 & 27.7 & 9.1 & 492 & 493 & 9609 & 25.9 \\
Maximum & 20,054 & 20,520 & 130.1 & 15.4 & 772 & 779 & 19,552 & 121.9 \\
COV: \% & 16.4 & 17.6 & 28.1 & 15.1 & 11 & 11 & 17.1 & 28.0 \\
Char.val. & - & - & - & - & - & 513 & 10,396 & 34.5 \\
\hline
\end{tabular}

${ }^{1}$ Computed according to EN 384 [33]. ${ }^{2}$ Computed according to EN 14,080 [34].

Table 3. Physical and mechanical properties for the NP sawn wood sample.

\begin{tabular}{|c|c|c|c|c|c|c|c|c|}
\hline & $\begin{array}{l}E_{d y n-b} \\
\mathrm{MPa}\end{array}$ & $\begin{array}{c}E_{\text {global-b }} \\
\mathbf{M P a}\end{array}$ & $\begin{array}{l}f_{m} \\
\text { MPa }\end{array}$ & $\begin{array}{l}w \\
\%\end{array}$ & $\begin{array}{c}\rho \\
\mathrm{kg} / \mathrm{m}^{3}\end{array}$ & $\begin{array}{l}\rho_{12} \% \\
\mathrm{~kg} / \mathrm{m}^{3}\end{array}$ & $\begin{array}{c}E_{\text {global-b-12\% }}{ }^{1} \\
\mathrm{MPa}\end{array}$ & $\begin{array}{c}f_{m \text {-adj }}{ }^{2} \\
\text { MPa }\end{array}$ \\
\hline Mean & $14,757^{\mathrm{a}}$ & 14,429 & 72.3 & 12.1 & 702 & $701^{\mathrm{a}}$ & $14,466^{\mathrm{a}}$ & $69.3^{\mathrm{a}}$ \\
\hline Minimum & 9420 & 8399 & 26.8 & 9.2 & 535 & 538 & 8618 & 25.7 \\
\hline Maximum & 18,137 & 17,660 & 129.1 & 16.8 & 803 & 808 & 17,514 & 123.8 \\
\hline COV: \% & 13.5 & 14.4 & 31.2 & 12.2 & 10 & 10 & 14.8 & 31.2 \\
\hline Char.val. & - & - & - & - & - & 581 & 11,193 & 42.7 \\
\hline
\end{tabular}

To perform an analysis of the experimental results, a detailed statistical analysis of variance (ANOVA), complemented with a $t$-test, was used. A confidence level of 0.05 was adopted. The analysis of Tables 2 and 3 clearly showed significant differences between the properties of the boards with different provenances (different letters, ${ }^{\mathrm{a}}$ and ${ }^{\mathrm{b}}$, indicate statistically significant differences between provenances). The analysis of the $p$-values corroborates this, with most of the listed properties presenting low values. Is the case of the density, dynamic and static MOE, for which $p$-values of 3.4 $\times 10^{-10}, 6.9 \times 10^{-3}$ and $2.7 \times 10^{-2}$ were observed, respectively. On the other hand, for the bending strength, there were no significant differences between provenances ( $p$-value $=6.2 \times 10^{-2}$ ).

The AI sample had a mean density of $593 \mathrm{~kg} / \mathrm{m}^{3}$ (with a coefficient of variation (COV) of $11 \%$ ), while the NP sample had a mean density of $701 \mathrm{~kg} / \mathrm{m}^{3}$ (with COV $=10 \%$ ): $18 \%$ higher than the mean density of the AI sample. In terms of dynamic MOE, mean values of 13,500 MPa and 14,800 MPa were measured for AI and NP samples, respectively. There is a difference between the two samples in the same direction as that found for the density, but with less expression; the dynamic MOE of the NP sample was $10 \%$ higher than the same property of the AI sample. In terms of static MOE, mean values of $13,600 \mathrm{MPa}(\mathrm{AI})$ and $14,400 \mathrm{MPa}(\mathrm{NP})$ were obtained. Considering the overall sample, density $\left(647 \mathrm{~kg} / \mathrm{m}^{3}\right)$ and static MOE $(13,908 \mathrm{MPa})$, were similar to previous values obtained for clear wood specimens by Machado et al. [20], which presented mean values of $654 \mathrm{~kg} / \mathrm{m}^{3}$ and 14,100 MPa for the same properties, respectively.

By comparing the results of this study on Blackwood with those from other hardwoods available in the Portuguese forest (Blue gum, Chestnut, and Poplar), Blackwood is not the strongest, but it has a very high density and mechanical properties. In comparison with Blue gum [29], Blackwood showed lower density $(-29 \%)$, static MOE $(-23 \%)$ and bending strength $(-13 \%)$. As for Poplar, the dynamic MOE of Blackwood was about 35\% higher [12,31], with a density ranging from $50 \%$ [12] to $59 \%$ [31] higher. On the other hand, if compared with the results obtained by Martins et al. [35] for Chestnut (a noble and durable species), Blackwood density and static MOE were $12 \%$ and 39\% higher. If considering a Spanish Sweet Chestnut [36], the values were slightly different, with the Portuguese Blackwood showing about the same characteristic density $(+2 \%)$, but lower characteristic static MOE $(-15 \%)$ and higher characteristic bending strength (32\%).

Beech (Fagus sylvatica L.) is one of the most-studied European hardwood species for structural applications. A comparison between the Portuguese Blackwood and Beech [37] in terms of mean values of density, static MOE, and bending strength showed small differences, for a sample with $85 \times$ 
$55 \mathrm{~mm}^{2}$ (width $\times$ thickness). Blackwood density and bending strength were $-6 \%$ and $-7 \%$ lower than the Beech's corresponding properties and, as for the static MOE, the Blackwood's was $5 \%$ higher than the Beech's. For a sample with $120 \times 55 \mathrm{~mm}^{2}$ (width $\times$ thickness), the difference in the Blackwood density and bending strength increased a little (in absolute value) to $-13 \%$ and $-19 \%$, respectively, while, for the static MOE, the difference relative to the previous sample was about the same (the Blackwood's was $6 \%$ higher than the Beech's).

A statistical analysis of the density and both MOE values revealed correlation coefficients of 0.66 for density $\left(\rho_{12} \%\right)$ vs. static $\operatorname{MOE}\left(E_{\text {global-b- } 12 \%}\right)$ and 0.68 for density $\left(\rho_{12} \%\right)$ vs. dynamic MOE $\left(E_{d y n-b}\right)$, considering the entire sample. If considering the different provenances, by relating the same quantities, the correlation coefficients were similar: $0.64(\mathrm{AI})$ and $0.69(\mathrm{NP})$; and $0.65(\mathrm{AI})$ and $0.68(\mathrm{NP})$, respectively. The $t$-test showed insignificant differences when using the LVM as a predictor of the static MOE ( $p$-value $=5.8 \times 10^{-1}$, considering the entire sample), which confirms this method as an effective and reliable tool. The correlation coefficients between the two variables $\left(E_{\text {dyn-b }}\right.$ vs. $\left.E_{\text {global-b-12\% }}\right)$ were 0.96, considering the entire sample, and 0.97 and 0.95 for AI and NP samples, respectively (Figure 5). Considering the bending strength prediction, correlation coefficients based on both dynamic and static

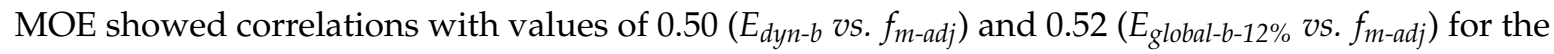
entire sample, 0.44 and 0.41 for the AI sample, and 0.50 and 0.52 for the NP sample, respectively.

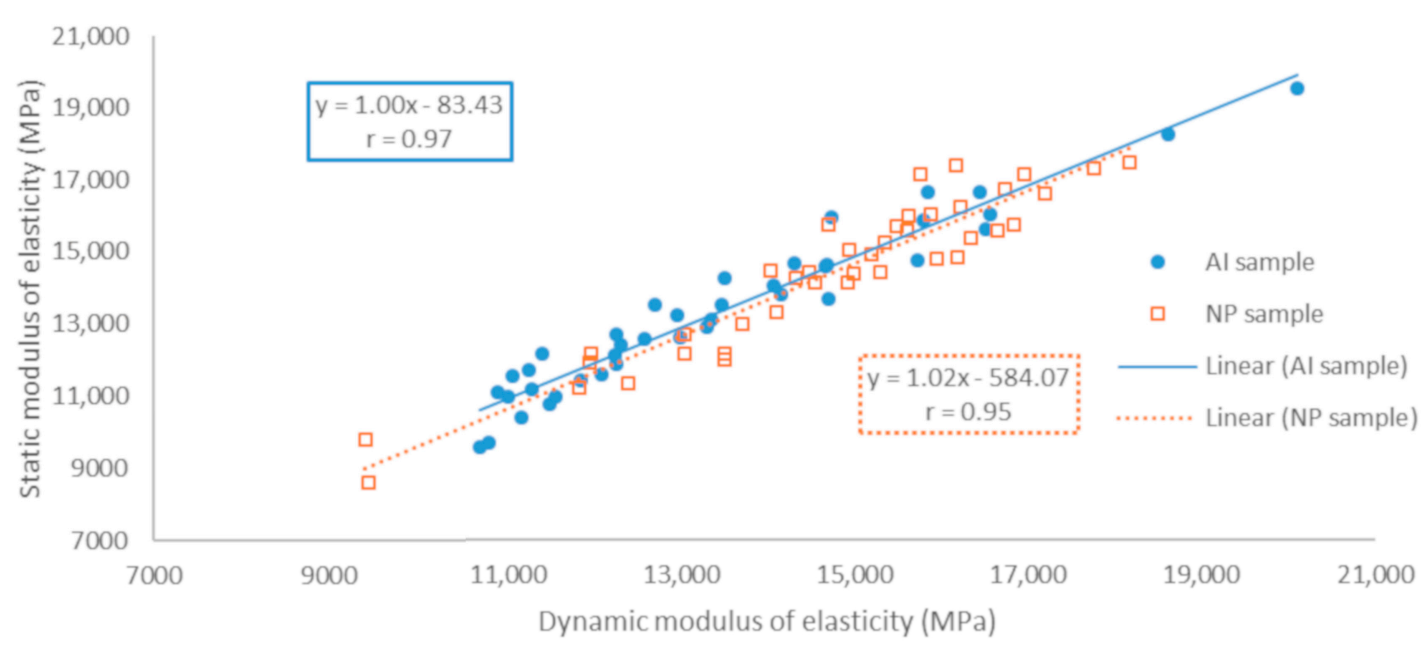

Figure 5. Correlation between dynamic $\left(E_{d y n}\right)$ and static $\operatorname{MOE}\left(E_{g l o b a l-b-12 \%}\right)$.

\subsection{Portuguese Blackwood Glulam Beams}

Table 4 gathers the estimated values for the MOE, obtained with the TSM $\left(E_{T S M}\right)$ and with the $\operatorname{LVM}\left(E_{\text {dyn }}\right)$, the bending strength $\left(f_{m}\right)$ and the local and global MOE $\left(E_{\text {local }}\right.$ and $\left.E_{\text {global }}\right)$, computed based on the EN 408 [32], the moisture content and the density. The adjusted properties (for a $w=12 \%$ ) such as the density $\left(\rho_{12} \%\right)$ and, the values of both static $\operatorname{MOE}\left(E_{l o c a l-12 \%}\right.$ and $\left.E_{\text {global- }-12 \%}\right)$, computed based on the EN 384 [33], or the values of the bending strength adjusted concerning the beam cross-section $\left(f_{m-a d j}\right)$, based on the recommendations of EN 14,080 [34], are also listed on Table 4. The characteristic values were computed considering the $5 \%$ percentile.

Table 4. Physical and mechanical properties for the Blackwood glulam beams.

\begin{tabular}{|c|c|c|c|c|c|c|c|c|c|c|c|}
\hline & $\begin{array}{l}E_{T S M} \\
\mathbf{M P a}\end{array}$ & $\begin{array}{l}E_{d y \mathrm{n}} \\
\mathrm{MPa}\end{array}$ & $\begin{array}{c}f_{m} \\
\mathrm{MPa}\end{array}$ & $\begin{array}{c}E_{\text {local }}{ }^{1} \\
\mathrm{MPa}\end{array}$ & $\underbrace{E_{\text {global }}}_{\mathrm{MPa}}{ }^{1}$ & $\begin{array}{l}w \\
\%\end{array}$ & $\begin{array}{c}\rho \\
\mathrm{kg} / \mathrm{m}^{3}\end{array}$ & $\begin{array}{l}\rho_{12 \%}{ }^{2} \\
\mathrm{~kg} / \mathrm{m}^{3}\end{array}$ & $\begin{array}{c}E_{\text {local-12\% }}{ }^{2} \\
\mathrm{MPa}\end{array}$ & $\underset{\mathrm{MPa}}{E_{\text {global-12\% }}{ }^{2}}$ & $\begin{array}{c}f_{m \text {-adj }}{ }^{3} \\
\text { MPa }\end{array}$ \\
\hline Mean & 15,048 & 14,129 & 88.8 & 17,569 & 14,377 & 13.1 & 671 & 679 & 17,764 & 14,533 & 83.9 \\
\hline Minimum & 12,802 & 12,807 & 69.3 & 13,852 & 12,086 & 11.5 & 599 & 600 & 14,074 & 12,280 & 65.5 \\
\hline Maximum & 17,261 & 15,896 & 102.3 & 21,231 & 16,197 & 13.8 & 744 & 746 & 21,571 & 16,456 & 96.7 \\
\hline COV: \% & 9.5 & 9.8 & 12.2 & 14.4 & 9.5 & 5.9 & 10 & 9 & 14.8 & 9.8 & 12.2 \\
\hline Char.val. & - & - & 73.5 & - & 12,532 & - & 601 & 606 & - & 12,632 & 69.4 \\
\hline
\end{tabular}

${ }^{1}$ Computed according to EN 408 [32]. ${ }^{2}$ Computed according to EN 384 [33]. ${ }^{3}$ Computed according to EN 14,080 [34]. 
Comparing the mean values of density and mean adjusted static MOE obtained for the glulam beams with the corresponding quantities obtained for the boards, the values were similar, with $\rho_{12} \%$ and $E_{\text {global }-12 \%}$ of the beams being $4 \%$ higher than the same quantities for the board samples. The $t$-test demonstrated insignificant differences between results from sawn wood and glulam beams with $p$-values of $4.6 \times 10^{-1}$ and $2.9 \times 10^{-1}$ for density and $E_{\text {global_12\%, respectively. However, the mean }}$ adjusted bending strength of the glulam beams was $29 \%$ higher than the same quantity for the board samples. This is corroborated by a $p$-value of $7.0 \times 10^{-4}$, showing significant differences between sawn wood and glulam beam results.

As was done with the Blackwood boards, the results found for these Blackwood glulam beams were also compared with those from studies using other hardwood species. Relative to Blue gum glulam beams [12], the ones made of Blackwood showed lower density ( $-31 \%)$, static MOE ( $-40 \%)$ and bending strength $(-31 \%)$. The differences found in terms of dynamic MOE were similar to those found for the static MOE ( $-37 \%$ associated with $E_{T S M}$ and $-36 \%$ associated with $\left.E_{d y n}\right)$. Considering different Eucalyptus clones (Eucalyptus grandis '330' and '329') [38], the differences were significant. Compared with the E. grandis ' 330 ' clone glulam beams, the Blackwood beams exhibited a lower density (-8\%), static MOE $(-17 \%)$ and bending strength (-10\%). If the comparison considers the E. grandis '329' clone beams, the beams made of Blackwood showed higher density (21\%), static MOE (25\%) and bending strength $(50 \%)$.

When compared with glulam beams made of Poplar (a sample composed by Populus alba, P. nigra and P. $\times$ canadensis), the dynamic MOE of Blackwood was about 39\% higher [31], with a density of 56\% [31] higher. These results are in line with the ones found comparing the boards of Poplar and Blackwood in the previous subsection. However, considering a different Poplar species $(P . \times$ euramericana, 'Neva' clone) [38] the differences were higher, with the Blackwood beams presenting higher density (73\%), static MOE (51\%), and bending strength (90\%).

The statistical analysis of the data collected in the present study also revealed that there were no significant differences between the values of LVM and static MOE ( $p$-value $\left.=5.8 \times 10^{-1}\right)$ and between TSM and static MOE ( $p$-value $\left.=4.8 \times 10^{-1}\right)$. Additionally, no significant differences were observed between the values of LVM and TSM $\left(p\right.$-value $\left.=2.1 \times 10^{-1}\right)$. As for the remaining properties, significant differences were found ( $p$-value $<0.05$ ). A simple linear correlation analysis, considering all beams, showed that there is an agreement between the density and both MOE with correlation coefficients of 0.94 and 0.90 for density $\left(\rho_{12} \%\right)$ vs. static MOE $\left(E_{\text {global }-12 \%}\right)$ and density $\left(\rho_{12} \%\right)$ vs. both dynamic LVM $\operatorname{MOE}\left(E_{d y n}\right)$ and dynamic TSM MOE $\left(E_{T S M}\right)$, respectively. Once again, the dynamic prediction of the static MOE, using either the LVM or the TSM, showed to be an effective and reliable tool. The correlation

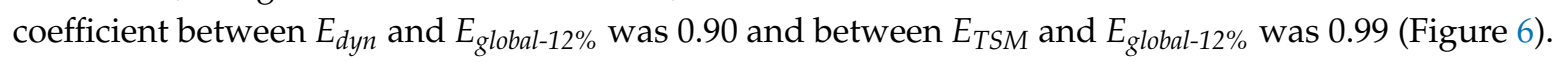
Figure 6 also gathers the correlation coefficients between the same properties for the homogenous and combined sets of beams (they are only indicative of a possible trend of the non-destructive approach to predicting the static MOE). Concerning the bending strength prediction, the correlation coefficients, based on both dynamic LVM and TSM and the static MOE showed correlations with values of 0.74 , 0.86 and 0.89 , respectively. 


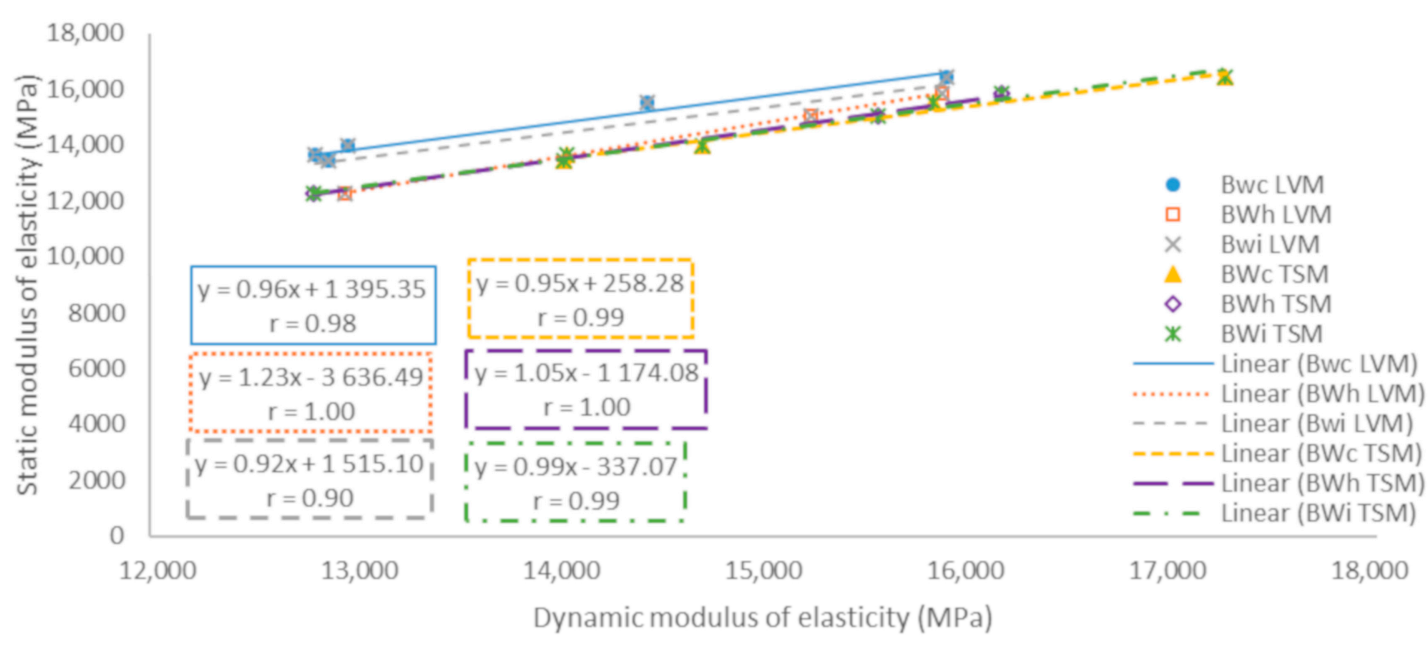

Figure 6. Correlation between dynamic $\left(E_{d y n}\right.$ and $\left.E_{T S M}\right)$ and static $\operatorname{MOE}\left(E_{\text {global-12\% }}\right)$. Bwc refers to the combined beams; Bwh refers to the homogenous beams; Bwi refers to the entire set of beams; Longitudinal Vibration Method (LVM); Transformed Section Method (TSM); Linear is the linear interpolation.

By comparing the results associated with the composite and homogeneous beams, the differences were very low, ranging between $-6 \%$ (associated with $E_{d y n}$ ) and $4 \%$ (associated with $f_{m}$ and $f_{m \text {-adj }}$ ). The composite beams had a mean dynamic MOE of about 13,800 $\mathrm{MPa}$, while the homogeneous beams' dynamic MOE was about 14,700 MPa. As for the mean adjusted bending strength, values of 85.2 MPa and 81.7 MPa were obtained for the composite and the homogenous beams, respectively. As expected, these differences demonstrate that the composite beams can use inner lamellae with lower quality, compared with the higher quality of the outer lamellae, without compromising the mechanical properties of the whole beam.

The structural efficiency, which relates a mechanical property (such as static MOE or bending strength) with density, for the glulam beams made of the various hardwood species was assessed and is presented in Table 5. In terms of the structural efficiency for the static MOE, Poplar beams showed the highest value (25.7 associated with P. alba, P. nigra and P. x canadensis species) and Blackwood beams showed a value close to the lowest in Table 5 (21.8). However, concerning the structural efficiency for the bending strength, the Blackwood beams showed the highest value (0.13), together with those made of E. grandis ' 330 '.

Table 5. Structural efficiency for $E_{g l o b a l-12 \%}$ and $f_{m}$ of glulam beams made of different hardwood species.

\begin{tabular}{cccc}
\hline Species & $E_{\text {global-12\%}} / \rho_{\mathbf{1 2} \%}$ & $f_{\text {m-adj }} / \rho_{\mathbf{1 2} \%}$ & Reference \\
\hline Blackwood & 21.8 & 0.13 & - \\
Blue gum & 23.1 & 0.12 & {$[12]$} \\
E. grandis '330' & 24.0 & 0.13 & {$[38]$} \\
E. grandis '329' & 21.0 & 0.10 & {$[38]$} \\
P. alba, P. nigra and $P . \times$ canadensis & 25.7 & 0.12 & {$[31]$} \\
P. $\times$ euramericana, 'Neva' & 25.0 & 0.11 & {$[38]$} \\
\hline
\end{tabular}

\section{Conclusions}

Acacia is, nowadays, considered an invasive species in the Portuguese forest. To avoid the harms that this can bring to other native species and, at the same time, increase its value, using it as a construction material can be a good solution. This study focuses on the assessment of the potential of using this Portuguese hardwood for construction applications, either as sawn material or as engineered products, such as glulam, making use of the raw material obtained from the proliferation of the species. Despite the fact that the use of wood-based products has been largely governed by softwood species, most of which are imported from Europe, the findings in this study may help to change this situation. 
The mechanical characterization of Portuguese Blackwood species showed the high density and mechanical properties of sawn wood (mean values of density, static MOE, and bending strength of $647.1 \mathrm{~kg} / \mathrm{m}^{3}, 13,900 \mathrm{MPa}$ and $65.2 \mathrm{MPa}$, respectively) and glulam beams (mean values of density, static $\mathrm{MOE}$, and bending strength of $678.5 \mathrm{~kg} / \mathrm{m}^{3}, 14,500 \mathrm{MPa}$ and $83.9 \mathrm{MPa}$, respectively). This demonstrates the great quality of the studied hardwood, and its potential to produce high value-added products. The use of the LVM provides a reliable way to characterize the quality of the Blackwood products, proven by correlation coefficients between dynamic and static properties above 0.90 . Thus, the prediction of the mechanical properties could be less time consuming and could avoid the breakage of material.

Hardwoods could be considered as an alternative to softwoods due to their fast growth rates and their inherent capacity to surpass the threat of climate change. The use of hardwood species for engineered wood products is also an alternative to softwoods, providing high-quality products with superior mechanical properties. Besides, in the case of the Portuguese Blackwood, it could also help to control the proliferation of these invasive species.

Author Contributions: A.D. and C.M. conceived the studied issue; S.K. provided the Blackwood boards; C.M. and S.M. performed the experimental tests, analyzed the data and wrote the paper, A.D. and S.K. wrote the paper. All authors have read and agreed to the published version of the manuscript.

Funding: This work was financed by FEDER and FSE funds through the CENTRO 2020 Regional Operational Programme within the scope of the Sustainable built Environment under Natural Hazards and Extreme Events (SUSpENsE) Project (CENTRO-01-0145-FEDER-000006).

Acknowledgments: The authors wish to thank Henkel and Jowat for providing the adhesives, and Azorina for providing the timber.

Conflicts of Interest: The authors declare no conflict of interest.

\section{References}

1. ICNF-Instituto da Conservação da Natureza e das Florestas [Institute for Nature Conservation and Forests]. Importância Económica [Economic importance]. 2019. Available online: http://www2.icnf.pt/portal/florestas/ fileiras/econ (accessed on 1 July 2019).

2. ICNF-Instituto da Conservação da Natureza e das Florestas [Institute for Nature Conservation and Forests]. IFN6-6. ${ }^{\circ}$; Inventário Florestal Nacional [6th National Forest Inventory]: Lisbon, Portugal, 2019; p. 284.

3. Knorz, M.; Schmidt, M.; Torno, S.; Van de Kuilen, J.W. Structural bonding of ash (Fraxinus excelsior L.): Resistance to delamination and performance in shearing tests. Eur. J. Wood Wood Prod. 2014, 72, $297-309$. [CrossRef]

4. Schlotzhauer, P.; Kovryga, A.; Emmerich, L.; Bollmus, S.; Van de Kuilen, J.W.; Militz, H. Analysis of Economic Feasibility of Ash and Maple Lamella Production for Glued Laminated Timber. Forests 2019, 10, 529. [CrossRef]

5. Schmidt, M.; Glos, P.; Wegener, G. Gluing of European beech wood for load bearing timber structures. Eur. J. Wood Wood Prod. 2010, 68, 43-57. [CrossRef]

6. Ohnesorge, D.; Richter, K.; Becker, G. Influence of wood properties and bonding parameters on bond durability of European Beech (Fagus sylvatica L.) glulams. Ann. For. Sci. 2010, 67, 601. [CrossRef]

7. Boruszewski, P.J.; Borysiuk, P.; Maminski, M.L.; Grzeskiewicz, M. Gluability of thermally modified beech and birch wood. Wood Mater. Sci. Eng. 2011, 6, 185-189. [CrossRef]

8. Martins, C. Avaliação Estrutural de Elementos de Madeira Lamelada Colada [Health Assessment of Glued Laminated Timber Elements]. Ph.D. Thesis, University of Coimbra, Coimbra, Portugal, October 2018.

9. Martins, C.; Dias, A.M.P.G.; Cruz, H. Glulam made by poplar: Delamination and shear strength tests. In Proceedings of the 6th International Scientific Conference on Hardwood Processing-ISCHP 2017, Lahti, Finland, 5-28 September 2017; pp. 222-231.

10. Monteiro, S.R.S.; Martins, C.E.J.; Dias, A.M.P.G.; Cruz, H. Mechanical Characterization of Clear Wood from Portuguese Poplar. Bioresources 2019, 14, 9677-9685.

11. Monteiro, S.R.S.; Martins, C.E.J.; Dias, A.M.P.G.; Cruz, H. Mechanical performance of wood-based products fabricated with Portuguese Poplar. Eur. J. Wood Wood Prod. under revision. 
12. Martins, C.; Dias, A.M.P.G.; Cruz, H. Blue gum: Assessment of its potential for load bearing structures. In Proceedings of the 7th International Conference on Hardwood Processing-ISCHP 2019, Delft, The Netherlands, 28-30 August 2019.

13. Knapic, S.; Tavares, F.; Pereira, H. Heartwood and sapwood variation in Acacia melanoxylon R. Br. trees in Portugal. Forestry 2006, 79, 371-380. [CrossRef]

14. Goes, E. A floresta portuguesa, sua importância e descrição das espécies de maior interesse [The Portuguese forest, its importance and description of the species of greatest interest]; Portucel: Lisbon, Portugal, 1991; p. 257.

15. Leite, A.; Santos, C.; Saraiva, I.; Pinho, J.R. O planeamento florestal e as espécies invasoras [Forest planning and invasive species]. In Proceedings of the $1 .^{\circ}$ Encontro de Invasoras Lenhosas [1st Meeting of Invasive Ligneous], Gerês, Portugal, 16th to 18th November 1999; Sociedade Portuguesa de Ciências Florestais [Portuguese Society of Forest Sciences]: Lisboa, Portugal, 1999; pp. 45-50.

16. Zwaan, J.G. The silviculture of blackwood (Acacia melanoxylon). S. Afr. For. J. 1982, 121, 39-43. [CrossRef]

17. Nicholas, G.J.; Brown, I. Blackwood. A handbook for growers and users; New Zealand Forest Research Institute: Rotorua, New Zealand, 2002.

18. Bradbury, G.J.; Beadle, C.L.; Potts, B.M. Genetic control in the survival, growth and form of Acacia melanoxylon. New For. 2010, 39, 139-156. [CrossRef]

19. Santos, A.; Simões, R.; Tavares, M. Variation of some wood macroscopic properties along the stem of Acacia melanoxylon R. Br. Adult trees in Portugal. For. Syst. 2013, 22, 463-470. [CrossRef]

20. Machado, J.S.; Louzada, J.L.; Santos, A.J.A.; Nunes, L.; Anjos, O.; Rodrigues, J.; Simões, R.M.S.; Pereira, H. Variation of wood density and mechanical properties of blackwood (Acacia melanoxylon R. Br.). Mater. Des. 2014, 56, 975-980. [CrossRef]

21. Lourenço, A.; Baptista, I.; Gominho, J.; Pereira, H. The influence of heartwood on the pulping properties of Acacia melanoxylon wood. J. Wood Sci. 2008, 54, 464-469. [CrossRef]

22. Anjos, O.; Santos, A.; Simões, A. Effect of Acacia melanoxylon fiber morphology on papermaking potential. Appita J. 2011, 64, 185-191.

23. Santos, A.J.A.; Anjos, O.M.S.; Simões, R.M.S. Papermaking potential of Acacia dealbata and Acacia melanoxylon. Appita J. 2006, 59, 58-64.

24. Tavares, F.; Louzada, J.L.; Pereira, H. Variation in wood density and ring width in Acacia melanoxylon at four sites in Portugal. Eur. J. For. Res. 2014, 133, 31-39. [CrossRef]

25. Medhurst, J.L.; Pinkard, E.A.; Beadle, C.L.; Worledge, D. Growthand stem form responses of plantation-grown Acacia melanoxylon (R. Br.) to form pruning and nurse-crop thinning. For. Ecol. Manag. 2003, 179, 183-193. [CrossRef]

26. Jennings, S.M.; Hichey, J.E.; Candy, S.G. Comparison of regeneration success of alternative silvicultural treatments in blackwood swamps. Tasforests 2000, 12, 55-68.

27. Dias, A.M.P.G.; Machado, J.S.; Santos, P. Uso de produtos de madeira de alto desempenho em aplicações estruturais [Use of high performance wood products in structural applications]. In Proceedings of the 5.as Jornadas Portuguesas de Engenharia de Estruturas [5th Portuguese Structural Engineering Days], Lisbon, Portugal, 26-28 November 2014.

28. Hodoušek, M.; Dias, A.M.P.G.; Martins, C.; Marques, A.; Böhm, M. Comparison of non-destructive methods based on natural frequency for determining the modulus of elasticity of Cupressus lusitanica and Populus $\times$ Canadensis. BioResources 2017, 12, 270-282. [CrossRef]

29. Martins, M. Caracterização do Eucalipto globulus para aplicação estrutural [Eucalyptus globulus characterization for structural applications]. Master's Thesis, University of Coimbra, Coimbra, Portugal, July 2015.

30. EU. Moisture Content of A Piece of Sawn Timber-Part. 2: Estimation by Electrical Resistance Method; EN 13183-2; CEN: Brussels, Belgium, 2002.

31. Martins, C.; Dias, A.M.P.G.; Cruz, H. Using non-destructive testing to predict the mechanical properties of glued laminated poplar. P I Civil. Eng-Str B 2019, 172, 661-670. [CrossRef]

32. EU. Timber Structures-Structural Timber and Glued Laminated Timber-Determination of Some Physical and Mechanical Properties; EN 408; CEN: Brussels, Belgium, 2012.

33. EU. Structural Timber and Glued Laminated Timber-Determination of Characteristic Values of Mechanical Properties and Density; EN 384; CEN: Brussels, Belgium, 2010. 
34. EU. Timber Structures-Glued Laminated Timber and Glued Solid Timber-Requirements; EN 14080; CEN: Brussels, Belgium, 2013.

35. Martins, C.; Dias, A.M.P.G.; Martins, H.; Jorge, L. Non destructive testing of Portuguese Chestnut beams. In Proceedings of the 4th International Conference on Hardwood Processing-ISCHP 2013, Florence, Italy, 7-9 October 2013.

36. Vega, A.; Arriaga, F.; Guaita, M.; Baño, V. Proposal for visual grading criteria of structural timber of sweet chestnut from Spain. Eur. J. Wood Wood Prod. 2013, 71, 529-532. [CrossRef]

37. Cibecchini, D.; Cavalli, A.; Goli, G.; Togniof, M. Beech sawn timber for structural use: A case study for mechanical characterization and optimization. the Italian visual strength grading rule. J. For. Sci. 2016, 62, 521-528. [CrossRef]

38. Castro, G.; Paganini, F. Mixed glued laminated timber of poplar and Eucalyptus grandis clones. Holz als Roh-und Werkstoff. 2003, 61, 291-298. [CrossRef]

(C) 2020 by the authors. Licensee MDPI, Basel, Switzerland. This article is an open access article distributed under the terms and conditions of the Creative Commons Attribution (CC BY) license (http://creativecommons.org/licenses/by/4.0/). 